\title{
Universities need leadership, academics need management: discursive tensions and voids in the deregulation of Swedish higher education legislation
}

\author{
Marianne Ekman ${ }^{1} \cdot$ Monica Lindgren ${ }^{1}$. \\ Johann Packendorff ${ }^{1}$
}

Published online: 10 April 2017

C) The Author(s) 2017. This article is published with open access at Springerlink.com

\begin{abstract}
In this article, we discuss how 'managerialist' and 'leaderist' discourses (O'Reilly and Reed Public Administration 88:960-978, 2010; Organization Studies 32:1079-1101, 2011) are drawn upon in the context of the deregulation of Swedish higher education. As of 2011, there has been new legislation that frames Swedish universities as 'autonomous' and transfers most of the regulative responsibilities from the government level to university vice-chancellors. The aim of this article is to inquire into how tensions within and between managerialist and leaderist discourse are handled in the promotion of New Public Management reforms and the consequences thereof in terms of how leadership in the higher education sector is constructed. We analyse how these discourses are employed in the core documents leading up to the 2010 Riksdag decision to enact most of the proposed deregulations, and the subsequent evaluation undertaken by the social democratic government that took over in 2014. Based in this analysis, we suggest that the texts indeed draw upon notions of leadership and leaders as necessary for Swedish universities to survive and thrive in the future, but that the envisaged practise of this 'strong leadership' can either be characterised as a discursive void or described in terms of depersonalised, instrumental managerial surveillance and control.
\end{abstract}

Keywords Higher education · Deregulation · Leaderism · Managerialism · New Public Management $\cdot$ Discourse analysis

Johann Packendorff

johann.packendorff@indek.kth.se

Marianne Ekman

marianne.ekman@indek.kth.se

Monica Lindgren

monica.lindgren@indek.kth.se

1 KTH Royal Institute of Technology, School of Industrial Engineering and Management, Department of Industrial Economics and Management, Lindstedtsvägen 30, 10044 Stockholm, Sweden 


\section{Introduction}

In this article, we discuss how 'managerialist' and 'leaderist' discourses (O'Reilly and Reed 2010, 2011) are drawn upon in the context of the deregulation of Swedish higher education. 'Managerialism' and 'leaderism' are then analysed as a 'set of beliefs that frames and justifies certain innovatory changes in contemporary organisational and managerial practice' (O'Reilly and Reed 2010: 960). We analyse how these discourses are employed in the core documents leading up to the 2010 Riksdag decision to enact most of the proposed deregulations, and the subsequent evaluation undertaken by the social democratic government that took over in 2014. Based on this analysis, we suggest that the texts indeed draw upon notions of leadership and leaders as necessary for Swedish universities to survive and thrive in the future, but that the practise of this 'strong leadership' is mainly described in terms of de-personalised, instrumental managerial surveillance and control.

In current research on the development of professional norms and ideals in public sector reform, the presence of discourse relating to forms of governance such as New Public Management (NPM) has been a recurring theme (cf. O’Reilly and Reed 2010, 2011; Martin and Learmonth 2012; Fitzgerald et al. 2013). Public sector management in profession-based organisations such as schools and universities is increasingly based on market mechanisms, corporate organisational structures and clear principles of accountability and responsibilityreplacing earlier policy technologies based on professionalism and civil service-inspired bureaucratic ideals (Marginson and Considine 2000; Ball 2003; Teelken 2012; Ahlbäck Öberg et al. 2016). According to O'Reilly and Reed (2011), over time this 'managerialism' has also been extended by a complementary discourse, 'leaderism'.

Leaderism is based in the promotion of individual leaders as radical change agents with the ability to define organisational agendas and solutions, unify diverging interests, attend to needs of consumers and citizens, and create enthusiasm and shared values in the organisation. More specifically, leaderist discourse projects hope onto a constructed ideal liberated leader, a rational and omnipotent actor to which the fates of complex organisations can be trusted (Meindl et al. 1985) and who possess certain generic qualities that are beneficial in any organisational context (Bresnen et al. 2015). He or she not only implements, but also designs, the necessary changes within a general framework set up by policymakers; he or she is 'an author of his or her own reforms'. Moreover, leaderism conveys an image of leadership as a positive and inspiring phenomenon, adding moral, aesthetic and spiritual qualities to the exercise of functionalist managerial techniques (cf. Currie and Lockett 2007).

However, neither managerialism nor leaderism is a homogenous, harmonious discourse. For example, O'Reilly and Reed (2010) refer to the inherent ambiguities and flexibility of leaderist discourse: it may at once contain notions of market-driven consumerism, top-down management techniques, inspirational leadership and dispersed responsibilisation of all professionals. Currie and Lockett (2007) note that several leadership ideals are at play simultaneously in public sector change, and that close government control is maintained despite claims of administrative freedom for managers. In a similar vein, Ford (2006) suggests that notions of leadership in organisations tend to incorporate many co-existing yet contradictory discourses that are drawn upon in identity work and in promoting managerial ideals. According to Crevani et al. 2015, this may result in discursive hybridisation, where different discourses on leadership are invoked at the same time and sometimes even confirm one another despite seemingly vast differences. Leadership thus become associated with almost anything that anyone can perceive as good or desirable, and as such it is an almost inescapable 
neoliberal discursive construct with a strong performative content: difficult, but not impossible, to subvert and resist (cf. Morrish and Sauntson 2010).

While these conceptions of managerialism and leaderism were studied earlier in relation to large quantities of material and/or time spans in order to trace general discursive developments (cf. O'Reilly and Reed 2010; Currie and Lockett 2007), we are interested here in patterns in how such tensions are handled in texts advocating a specific NPM-inspired reform (cf. Bresnen et al. 2015). Such an approach not only enables us to make an in-depth analysis of what discursive aspects are simultaneously at play and how inherent tensions are handled, but also to contribute to a more detailed understanding of how managerialist and leaderist discourses operate in policy formulation.

The aim of this article is thus to inquire into how tensions within and between managerialist and leaderist discourse are handled in the promotion of NPM reforms and the consequences thereof in terms of how leadership in the higher education sector is constructed. We thus add to earlier studies on higher-education reform and leadership (cf. Reed 2002; Deem 2004; Bleiklie and Lange 2010; Clarke et al. 2012; Bolden et al. 2014) by providing a conceptualisation of how different discursive influences are simultaneously invoked in the ongoing production of truth claims. In this way, we will show how the discourses of managerialism and leaderism are present in government texts on university reform, but that these discourses are laden with tensions: not only are there contradictions and anticipated resistance but also a discursive void as to how leadership is related to the upcoming reforms, a void that is 'filled' with notions of instrumental management rather than the enthusing and motivating aspects usually associated with 'leadership'.

\section{New Public Management (NPM), managerialism and leaderism}

Since the 1980s, NPM has been a general international trend in public sector reform, driven by policy discourses that view the public sector as bureaucratic, conservative, self-serving, ineffective, and dominated by internal professional norms (Hood 1995). NPM thus implies a reversal of the two founding doctrines of traditional public management: the doctrine of sustaining the distinctiveness of the public sector vis-à-vis the private one, and the doctrine of emphasising rules and norms to guarantee procedural justice. Instead, under NPM, the boundaries between public and private sector organising are dissolved, and the focus is redirected from process regulation to results and outcomes-implying an agenda of procedural deregulation and increased emphasis on performance measurement.

At the core of NPM, we find the managerialist discourse - emphasising the management of public sector organisations through rational structures, standardised procedures, and clearly defined notions of responsibility and accountability (Clarke and Newman 1997; Pollitt 1990; Reed 2002; Terry 1998). Managerialism has been introduced as a set of organisational and social technologies for the efficient management of organisational matters, construing public sector organisations as in need of being 'managed' and clients/ taxpayers as consumers operating in a turbulent marketplace (Crevani et al. 2015). According to O'Reilly and Reed (2010), managerialism contains an aspect of entrepreneurship (non-bureaucratic organising for innovation in a competitive market) and an aspect of cultural engineering (aligning policymakers and public sector managers in terms of beliefs and strategic orientation) (Table 1). 
Table 1 Professionalism, managerialism and leaderism as discursive foundations of public service reform (adapted from O'Reilly and Reed 2011: 1085)

\begin{tabular}{|c|c|c|c|}
\hline & Professionalism & Managerialism & Leaderism \\
\hline $\begin{array}{l}\text { Service } \\
\text { ideology }\end{array}$ & Provider-driven - mitigated in documents & 'Performance'-driven & Community-driven \\
\hline $\begin{array}{l}\text { Knowledge } \\
\text { base }\end{array}$ & Specialised 'professionalisation' & Centralised hierarchy & $\begin{array}{l}\text { Distributed-dispersed } \\
\text { leadership }\end{array}$ \\
\hline $\begin{array}{l}\text { Strategic } \\
\text { focus }\end{array}$ & Custodial-'professional leadership' & $\begin{array}{l}\text { Technocratic } \\
\text { ('performance', } \\
\text { disciplines and domains) } \\
\text { and consumerist }\end{array}$ & $\begin{array}{l}\text { Technocratic } \\
\text { ('performance') and } \\
\text { custodial ('local } \\
\text { leadership') }\end{array}$ \\
\hline $\begin{array}{l}\text { Essential } \\
\text { features }\end{array}$ & Expertise & Management autonomy & Grit of leadership \\
\hline $\begin{array}{l}\text { Service } \\
\text { improve- } \\
\text { ment }\end{array}$ & Professionalisation & $\begin{array}{l}\text { Better management } \\
\text { techniques }\end{array}$ & $\begin{array}{l}\text { 'Strategic leadership' } \\
\text { by government }\end{array}$ \\
\hline $\begin{array}{l}\text { Regulative } \\
\text { mode }\end{array}$ & $\begin{array}{l}\text { Expert autonomy, light touch regulation } \\
\text { and inspection-mitigated in } \\
\text { documents by multiple collaborations, } \\
\text { measurement and incorporation of elite } \\
\text { professionals }\end{array}$ & $\begin{array}{l}\text { Organisational control } \\
\text { Collaboration-with } \\
\text { government and } \\
\text { 'system' management }\end{array}$ & $\begin{array}{l}\text { Dispersed } \\
\text { leadership_-but } \\
\text { strategic leadership } \\
\text { by government } \\
\text { Involvement - of users } \\
\text { and stakeholders }\end{array}$ \\
\hline
\end{tabular}

In O'Reilly and Reed's (2010, 2011) study, it is suggested that managerialist discourses have been expanded by an emerging 'leaderist' discourse that has developed into a key feature of UK public service reform since the 1990s. 'Leaderism' is outlined by O'Reilly and Reed (2010) as 'the belief that many core aspects of social life can and should be co-ordinated by one or more individuals who give direction and/or purpose to social activity conducted by themselves and others' (p. 964). To make this concrete, they propose a set of 'metaphorical narratives' that are typically drawn upon to explain and support the need for leadership in organisations (ibid.):

- "that in an endemic situation of competition, survival and progress require social coordination;

- social co-ordination is best achieved through single or small groups of specially gifted and/ or positioned individuals who lead;

- individuals that lead use particular moral, intellectual, interpersonal, conative, material, or politico-cultural, resources in order to achieve social co-ordination;

- such social co-ordination by those who lead places them in a pre-eminent role;

- to perform this role leaders must be empowered by giving them sufficient room to manoeuvre - the 'right', or authority, to lead [...];

- those who lead require effort and commitment from those being led;

- such social co-ordination leads to progress which benefits all those involved."

As this 'leaderist' discourse builds on existing managerialist discourses, it also brings on a legacy of inherent tensions, such as free-minded entrepreneurship versus cultural control, or rational alignment versus passion for common goals. Likewise, public sector professionals are usually described either as victims of de-professionalisation or as strategic actors actively opposing managerialism (Gleeson and Knights 2006). In their conceptualisation of 
'leaderism', O'Reilly and Reed (2010) do indeed mention new potential tensions, such as collective co-ordination versus individual control, although that is not the main focus of their study. The leadership-related discursive resources available in society tend to grant primacy to the notion of the single, heroic, masculine leader as the norm for modern and effective leadership and scholarship (cf. Crevani et al. 2010; O'Reilly and Reed 2010; Bolden et al. 2014, Holgersson 2013; Van den Brink and Stobbe 2014; Wahl 2014). This leader-centrism has been heavily criticised by an increasing number of leadership scholars, and alternative ways of conceptualising and practising leadership have been proposed (cf. Crevani et al. 2010; Alvesson and Spicer 2012; Denis et al. 2012; Fitzgerald et al. 2013). While such alternative methods - such as shared leadership or distributed leadership (cf. Crevani et al. 2007) — are usually framed as new, alternative and suppressed notions of leadership, they are at the same time well established in traditional professional discourses of higher education. As noted by Bolden et al. (2014), universities are now moving towards an individualistic and heroic leadership ideal where the

“...emerging forms of leadership and management practice may be experienced as conflicting with ideals of collegiality, academic freedom, education and scholarship, ultimately distancing and disengaging the very people that universities seek to influence and involve in institutional governance, strategy and change." (Ibid: 755)

While building on the above-described notion of a 'leaderist' discourse, we are further interested in the inherent tensions of this discourse, and the potential for dialectical thinking in using the concept for critical analysis. Like Collinson (2014), Gleeson and Knights (2006), and Zoller and Fairhurst (2007), we acknowledge the need for awareness of how tensions are not only suppressed and hidden aspects of discourses but are also drawn upon in establishing 'regimes of truth' - acceptable formulations of problems and solutions. As noted by Stenson and Watt (1999), Jones and Spicer (2005), and Berglund et al. (2017), discursive processes also tend to create hidden agendas, agents, objects of concern and counter-narratives, which may be mobilised out of the picture. Such downplayed and discarded discursive elements are still of interest in the analysis - as voids and absences.

\section{Leaderism in Swedish higher education: a study of government inquiry reports}

The texts chosen for closer analysis are public government reports issued and authored by Swedish government bodies and their designated inquiry teams as part of the process of deregulating the Swedish higher education sector during the period 2006-2011 and the subsequent evaluation in 2015 (see Table 2). This set of documents is exhaustive is the sense that all official government material relating to the deregulation is included, but of course also limited, as we have excluded all other possible texts written on the subject during the period. We view the material as providing a legitimising context for political reforms in higher education, which implies an interest in what aspects of leadership and organisation are seen as acceptable/desirable or unacceptable/undesirable and what social orders are promoted. Inspired by the procedures developed by Martin and Learmonth (2012), the analysis was performed in two stages. The first stage involved tracing notions of leadership in the material and how these were described and promoted. In the next stage, we used these themes to unpack the discursive tensions and voids in the material. 
Table 2 Texts studied in the analysis of discourses of leadership in deregulation

$\begin{array}{ll}\begin{array}{l}\text { Quote } \\ \text { reference }\end{array} & \text { Reference }\end{array}$

ID CFQ Swedish Government (2006). Employment 2006 structures at universities and university colleges. Dir. 2006:48.

ID AI Swedish Government (2007). Greater freedom for 2007 universities and other higher education institutions. Dir. 2007:158.

IR CFQ Governmental Public Inquiries (2007). Careers 2007 for quality. SOU 2007:98.

IR AI Governmental Public Inquiries (2008). Autono2008 mous universities. SOU 2008:104.

GP AIIT Swedish Government (2010). An academy in its 2010 time - increased freedom for universities and university colleges. Govt Bill 2009/10:149.

ID Swedish Government (2014) Management funcMFH- tions in higher education. Dir. 2014:70.

D 2014

AID Swedish Government (2015) Additional direcMFH- $\quad$ tives to the Management Inquiry. Dir 2015:44. $\mathrm{D}$ 2015

PIR MI Governmental Public Inquiries (2015a). Partial 2015 report from the Management Inquiry. U2014:11.

IR MI Governmental Public Inquiries (2015b). Devel2015 oped management of higher education institutions. SOU 2015:92.
Directives from the social democratic government to the inquiry commission instructed to propose changes to the Higher Education Act concerning the central regulation of academic positions. (11 pages, 11 pages analysed)

Directives from the liberal/conservative government to the inquiry commission instructed to propose changes to the Higher Education Act implying increased autonomy for university vice-chancellors. (14 pages, 14 pages analysed)

Inquiry report 'Careers for quality', which responded to ID CFQ 2006 and assessed the functionality of current academic leadership and employment structures and proposed new such structures. (532 pages, 324 pages analysed)

Inquiry report 'Autonomous universities', which responded to ID AI 2007 and examined the allocation of authority between central government and universities and proposed a major transferral of authority to vice-chancellors and university boards. (303 pages, 213 pages analysed)

Bill from the liberal/conservative government to enact most (but not all) of the changes to the Higher Education Act proposed in the two inquiries. The Riksdag voted in favour of the proposition, which was enacted in the beginning of 2011. (153 pages, 106 pages analysed)

Directives from the liberal/conservative government to the inquiry commission instructed to propose voluntary changes in the governance structures of universities, and to consider needs for new governmental regulation. (19 pages, 19 pages analysed)

Expanded directives from the social democratic/green government to the same inquiry initiated through ID MFHD 2015. Instruction to also propose regulatory changes in how university boards are composed and elected. (2 pages, 2 pages analysed)

Partial report from the Management Inquiry, responding mainly to the additional directive given in AID MFHD 2015, proposing new procedures in electing university boards. (69 pages, 27 pages analysed)

Inquiry report mapping and evaluating the consequences of the 2011 deregulation, proposing an increased emphasis on line-oriented management structures in universities. The report also contains a knowledge overview on academic leadership. (513 pages, 374 pages analysed) 
All materials were downloaded in electronic form from the official websites of the Swedish government (www.regeringen.se) or the Riksdag (www.riksdagen.se); see URLs in the reference list. The co-authors then collectively undertook a general selection in the materials of text excerpts relating to governance and management of universities. ${ }^{1}$ This entailed omitting large parts of the reports, including proposed legislative formulations, definitions of financial technicalities, statistical materials and attached copies of earlier directives. Through this process, the material was reduced from 1616 to 1090 pages.

All co-authors then independently read the materials and marked sections related to leadership and management. We also performed a keyword search in both Swedish and English for the terms lead*, manag*, and admin* and marked the text around these terms. We were interested in how these terms and associated terms were defined and constructed, what higher education stakeholders were asked to do or not to do, and what role(s) were ascribed these stakeholders (cf. Martin and Learmonth 2012). Almost all marked text excerpts were found in the four inquiry reports and the 2010 government bill, while inquiry directives mainly provided us with necessary background information on the inquiries. The predominant sources of text excerpts were the two inquiry texts explicitly focusing on careers, employment condition and leadership in the higher education sector: 'Careers for Quality' (Governmental Public Inquiries 2007) and 'Developed management of higher education institutions' (Governmental Public Inquiries 2015b).

In this first stage of the analysis, we discerned five inter-related themes: (1) the framing of current forms and practises for management and leadership as 'traditional' in relation to many other alternatives; (2) the framing of collegiate forms as 'weak' and HEIs in need of 'strong leadership'; (3) descriptions of academics as poor followers and mainly interested in leading themselves; (4) descriptions of current academic leaders as trapped in webs of intra-faculty loyalties and ignorant of the managerial authorities and responsibilities that they already possess; and — which was a discursive shift occurring as the inquiries were taken up by politicians - (5) the need to circumscribe academic leaders by retaining some regulations.

In the second stage of the analysis, these themes were further analysed with the intention to identify tensions and voids in how the leaderist discourse were mobilised in the materials. The team of authors collectively re-read the text excerpts in order to determine how tensions in the texts reflected underlying tensions within the leaderist discourse, and in what way(s) these tensions were handled. Following O'Reilly and Reed (2010, 2011), we found that notions of leaders and leadership in this material contained a tension between liberation and sustained control of the leadership function, and a tension between instrumental and emotional modes of management and leadership. In addition, we found a lack of ideas in the material as to how leadership was supposed to be practised and what it was supposed to deliver to HEI stakeholders, i.e. a discursive gap related to the description of 'strong leadership' as a necessary precondition of the desired developments rather than integral to them.

\footnotetext{
${ }^{1}$ Throughout this section we will refer to the higher education sector in Sweden as either 'the academic sector' or 'universities'. The Swedish formal distinction between universities (universitet) and 'university colleges' (högskolor) will thus not be visible here. In short, the term universitet (a university) refers to a full research university, while a högskola (a 'university college') is a teaching organisation without any general right to award $\mathrm{PhD}$ exams. In the government texts analysed, this distinction is not used; the analyses and propositions concern the entire academic sector.
} 


\section{Findings: leaderist themes in the government reports}

In this section, we will trace a number of discursive themes occurring in the government texts discussed in the previous section. Most of the quotations were originally in Swedish (SW) and have thus been translated by the authors, but some are taken from the English (EN) summaries provided in the three inquiry reports.

\section{Traditional governance or modern leadership}

The initial texts - the inquiry directives issued by the government through the Ministry of Education and Research-provide various reasons for the intended deregulations, such as employee demographics, increased global competition and unfounded assumptions of eternal growth. These circumstances become the foundation of the managerialist assumption that an autonomous university, liberated from detailed legislative regulations, is far better equipped to handle the new, increased external and internal complexities. However, the autonomous university still has to be managed, and in creating an inventory of possible organisational forms, the inquiry teams claim to find advantages and disadvantages in all. Instead, they recommend a combination of forms, although the new managerialist ideas tend to be presented in favourable terms and contrasted against existing forms. The following quotation is typical of this:

Over the years, managerial forms within the academic sector have been influenced by various role models:

1. A classic form with roots in the academic sector, the school system and older government authorities is the 'collegial form'. It is especially beneficial in areas where decision processes must involve expertise from several fields.

2. Another model, one that draws upon private companies, non-governmental organisations and some government authorities, is the board of directors, where most of the members are recruited based on their relationship to external perspectives and competencies.

3. A third form of governance is the 'internal-democratic form', which is based on the idea of a representative balance between the various stakeholder groups: teachers, students and other employees.

4. A final governance form emphasises active leadership, personified by an action-oriented vice-chancellor supported by an active management team. The role models here are the CEOs of private corporations and monocratic managers in the public sector. (IR AI 2008 pp. 174-175) (SW)

The discursive notion of efficient private-sector management is introduced here - in terms both contrasting and complementary. This management ideal originates outside the university sector and is favourably described in terms of 'active' and 'action-oriented' leaders, tacitly suggesting that the other forms and their inhabitants lack these characteristics. At the same time it is an individualistic complement to the other, collective forms - but one clearly designated for the vice-chancellor position. What is 'new' or 'modern' is the very notion of leadership, brought in from outside to revitalise existing 'old' and 'traditional' management structures. Leadership and management is even framed as something that does not exist at all today: 
"The historic tradition that Academia should not be governed at all, and that its operations shall be developed without any plan, does not work given today's demands and challenges from society and internationally. This is not about managing the contents of teaching and research from above, that shall-according to the Higher Education Ordinance-be decided by teachers and researchers themselves. It is, however, about the existence of wellfunctioning management, in order to establish priorities on profiling and the general subject area of focus the university shall have concerning its education and research, and how this profile and focus shall be developed in strategic terms. Swedish universities operate in a totally different context today than they did 20-25 years ago.” (IR MI 2015, p. 85f) (SW)

The claimed absence of modern forms of management and leadership in practice is accompanied by both neglect and scepticism concerning what contemporary research in these fields can contribute to the development of Swedish universities. Effectively, this implies that leadership is seen as a matter of practical experience rather than of academic scholarship:

"It would of course be desirable to have some sort of empirical and unprejudiced investigation of how collegiate management forms work and to what extent assumed weaknesses exist in practice. This inquiry [team] has searched for such analyses but without any results. The problem is likely that empirical operationalisation of collegiate management and decisive leadership is missing. What can be found are descriptions and testimonies based in personal experiences and opinions." (IR MI 2015, p. 143f) (SW)

\section{Freedom and control: leadership and organisational liberation}

Throughout the texts, the importance of 'strong' and 'powerful' leadership is emphasised, while autonomy and liberation at all levels are lauded - discursively relating leadership not to control but rather to new aspects of the traditional notion of academic freedom. This is handled in the texts through the introduction of 'administrative freedom' - the right to manage:

Researchers must be independent and free in their role as seekers and creators of new knowledge. Academic freedom, however, is not the same as institutional or administrative freedom. Concentration, profile development and cooperation together with increased competition for research resources in Europe and globally require greater strategic leadership. The Inquiry's point of departure is that this type of more extensive strategic responsibility for an organisation and its staff is conditional on higher education institutions having greater freedom to set up rules for recruitment, appointments and promotion locally. (IR CFQ 2007 p. 36) (EN)

This reasoning is further explained later on by relating 'academic freedom' to 'collegiate' organisational structures, and 'administrative freedom' to unitary command and strong leadership. The collegiate structures are presented as more or less unable to prioritise between different areas of research, acting from a confused view of academic freedom as unlimited opportunities to explore any field of choice: 
"A majority among the individuals interviewed by the inquiry team bear witness of experiences that it are difficult for collegiate bodies to prioritise in terms of, for example, resource allocation, organizational changes or closing down parts of the operations. The inquiry team has received several descriptions of how strong collegiate structures rather tend to have a preserving effect. Research leaders from one of the older universities described the function of the faculty board as reactive, not pro-active. Another researcher claimed, from his experience of departmental board work, that different interests in a collegiate order become a struggle regarding monetary resources which results in the least common denominator, and 'taking a new bold decision, that just does not happen'." IR MI 2015, p. 182 (SW)

The Swedish system of granting tenured senior lecturers the right to apply for promotion to full professor - which was left to the discretion of the individual universities as part of the deregulation - is also criticised in the initial texts. Recruitment of full professors is a matter of strategic leadership, it is maintained, and if strategic leaders cannot control the current promotion system, universities are not as flexible as they need to be:

If a decision to promote is seen as an expression of strategic considerations, it is easy to interpret it in terms of a permanence that in no way corresponds to subsequent years' organisational needs. There is a clear risk that this order supports the individualistic culture that so often comes into conflict with more strategic considerations within the academic sector. A relatively free right to manage is a basic tenet upon which a strategic and satisfactory leadership must rest. (IR CFQ 2007 p. 239) (SW)

Who, then, are these individuals who are asked to take on the challenge of becoming active, strong and powerful leaders? Although this is not discussed much in the texts, there is some argumentation of leadership as a matter of personal qualities and thus much more an individualised occupation than that of teacher or researcher:

"The most important aspect of successful leadership - also emphasized by most people interviewed by the inquiry team - is the personal characteristics and qualities of the leader. It is evident that this is the crucial aspect of all sorts of managerial assignments." (IR MI 2015, p. 259) (SW)

Collegiate organisational forms, mainly the faculty boards prescribed by the existing legislation, are further claimed to be 'slow', 'ineffective' and 'conservative', often by reference to hidden and/or silent majorities:

Many are of the opinion that the regulations of the Higher Education Act and the Higher Education Ordinance are an obstacle to the emergence of effective leadership in universities. Some are critical to the widespread meeting culture that is claimed to exist in different boards and administrative units. The collegiate decision boards are perceived as ineffective and strongly conserving power factors. (IR AI 2008 p126) (SW)

The argumentation for increased managerial control and administrative freedom pays considerable attention to the recruitment, promotion and dismissal of teachers and researchers. 
Systems such as tenure and general promotion schemes are seen as resulting in a severe lack of flexibility, and they are rejected through references to general inevitable 'trends':

Employment conditions in universities tend to become increasingly equivalent to employment conditions in other areas of the labour market. Another trend is that the national policy is designed to promote values such as efficiency, control, responsibility (accountability) and management in universities. The increasing share of external funding is yet another trend contributing to the rise of management-type forms of decision-making and organisation within universities. (IR CFQ 2007 p182) (SW)

The fears that the proposed changes would impinge upon the academic freedom of scholars are also rejected, by claiming that hierarchical and collegiate forms of governance are equally equipped to impose limitations on research and free thought:

\begin{abstract}
"The possibility for teachers and researchers to design the contents of their teaching or their independent right to choose research problems, develop research methods or publish research results can be limited in an independent university. It can also be limited in a university with collegiate governance. It is doubtful whether there are any significant difference between line management and collegiate management in terms of safeguarding the academic freedom of individual teachers and researchers. Irrespective of whether he or she reports to a line manager or a collegiate body, both these leadership functions can either interfere in an inappropriate manner or grant significant leeway for the teacher or researcher to make his own decision about teaching or research." (IR MI 2015, p. 140)
\end{abstract}

\title{
The reluctant followers: employees as narrow-minded individualists
}

As mentioned above, the notion that academic freedom currently tends to be misinterpreted and misused is a common theme in the texts. Such misinterpretation - that is, the idea that a researcher can choose what he or she would like to do at work-is the subject of repeated remarks:

\begin{abstract}
Academic freedom is protected by law, and the individual curiosity of the researcher is the prime driver of knowledge creation. These are important components that must of course be safeguarded. On the other hand, from that, it does not follow that individual researchers have an unlimited right to do what they want-academic freedom does not imply administrative freedom. What is protected by law is free choice in research problems, free development of research methods and free publication of results. (IR CFQ 2007 p. 326) (SW)
\end{abstract}

This tradition is explained mainly by reference to the average academic employee as a conservative individualist, claiming that academics largely want to lead themselves and that they are trained to resist any visible hand: 
It is no secret that teachers and researchers do not need leaders and that the academic world does not welcome change. At the same time, acknowledgement of and respect for well-founded facts is a basic guiding principle for teachers and researchers at universities. [...] There is an apparent reluctance, and sometimes open hostility, towards leading and leadership in the academic sector. Academic freedom is often seen as diametrically opposed to leading. This can be ascribed to historical factors as well as to researchers' innate drive to question things and find new pathways. (IR CFQ 2007 p. 339) (SW)

The text continues by questioning the traditions of collegiate forms of decision-making and rotating leadership:

The academic leader, which refers primarily to vice-chancellors, deans and heads of departments, is chosen to fulfil a certain authoritative duty. At the same time, these leaders are by default a part of the faculty — primus inter pares. [...] There is, however, a risk that the will of the collegiate group becomes more important than the will of the leader, in a process of consensus. Thus there is a risk that the role of the academic leader becomes one of representing the group and articulating its voice rather than leading it and making necessary and sometimes uncomfortable decisions. [...] An equally important aspect of this problem is that after some years in the position, the leader often has to be re-integrated into the researcher collective. (IR CFQ 2007 p. 339) (SW)

\section{Reluctant leaders - trapped by regulations and archaic traditions}

Returning to the notion of unceasing growth as a fundamental reason for the lack of leadership in universities, the texts emphasise the lack of employer responsibility - that is, the assumption of the formal duty of representing the organisation in relation to the employees - amongst the current managers. This lack of employer responsibility is first discussed in terms of depriving the employees of the care and attention that they would automatically receive in other forms of organisations:

In the academic sector, the leadership culture is closely tied to the employer culture. Structures that are basically individualised have resulted in insufficient employer responsibility for teachers and researchers. It would appear natural that those who shape their — and their associates' — conditions are also responsible for their associates. [...] If the employer role in the academic sector is to be reformed according to the inquiry directives, into a modern, strategic and active employer role whereby universities act more like other employers in the labour market, this attitude must be fundamentally changed. (IR CFQ 2007 p. 96) (SW)

The focus is then redirected to the incontestable fact that in exercising strong and flexible leadership, future academic managers will have to dismiss employees if they want their organisations to thrive:

Dismissals are of course not desirable, but in an increasingly flexible and rapidly changing labour market, the academic sector cannot expect to be spared from this issue. Tenured teachers and researchers who until now have been relatively protected by the 
above-mentioned employer culture will see the relative precariousness of their jobs increase. Such a development will of course make the academic career less attractive than before, but there are no alternatives that will not damage the quality of the operations in the long run. (IR CFQ 2007 p. 97) (SW)

Academic managers are also presented with the challenge of combining this new responsibility with the need to enhance the attractiveness of their organisations:

The point of departure is the rules of the game of the labour market in general, and if universities want to be able to act as other employers in other situations, they must assume this responsibility. In addition, there are significant strategic reasons why universities should endeavour to become more attractive workplaces with the potential to recruit the best and the brightest. (IR CFQ 2007 p. 289)

The final government proposition takes the same perspective - although, as we shall see, some important exceptions are made:

On the contrary, the detailed regulation on recruitment and employment in the Higher Education Ordinance is, according to the government, an obstacle to an employer's actively assuming employer responsibility. The present order can imply that human resource issues become a matter for specialists in a detailed set of regulations rather than the central strategic issue that they really are. (GP AIIT 2010 p. 54) (SW)

\section{The partially empowered vice-chancellor: 'deregulation lite'?}

The texts contain several expressions of trust in the ability of future vice-chancellors to set up managerial hierarchies that will ensure universities possess the desired flexibility and innovativeness. In the proposal to the Riksdag, the government declares its full confidence in the vice-chancellors:

A consequence of increased freedom and decreased political governance is that the responsibilities of universities will increase significantly. The government concludes that this creates a foundation for long-term quality improvements. The proposals and considerations articulated in this proposition rest upon the readiness of universities to independently assume increased responsibility. They also imply increased demands on university management. (GP AIIT 2010 p. 16)

While most of the deregulation occurred through the simple deletion of rules and norms in the Higher Education Act and the Higher Education Ordinance - transferring increased authority to the vice-chancellors - there are some important caveats, a discourse of expected failure and lack of trust. In all the texts, a number of issues are raised whereby total deregulation is considered questionable or even detrimental. We have identified three such issues: recruitment, gender equality and collegial organisational forms, interestingly enough, related to the organisational matters in which empowered leadership is seen as the future solution.

The first issue is the recruitment of higher academic professionals, which - contrary to what one might expect - is not seen as an issue that can be totally left to the discretion of 
vice-chancellors. Instead, competence requirements for vice-chancellors are introduced - they must be eligible for a position as full professor or senior lecturer-and the recruitment procedures for senior lecturers and full professors will be subject to continued central regulation:

Against this background, the government proposes that an ongoing regulation be incorporated into the Higher Education Act, such that teaching and research require professors and senior lecturers to be employed at the universities. One of the aims of the regulation of senior lecturers would thus be to secure the presence of scientifically competent teachers in addition to professors, in order to maintain quality and the linking of scientific research to teaching. This proposal would secure the importance of university positions. (GP AIIT 2010 p. 57) (SW)

The second issue on which universities are not entirely trusted is gender equality in recruitment and promotion. Throughout the inquiry reports, the proclivity of empowered managers to attend to gender equality is brought into question, and local re-regulation proposed:

The increased autonomy in the management of human resources triggers legitimate questions about gender equality and whether women's ability to pursue an academic career is negatively affected by the proposals of this inquiry. It is usually pointed out that the presence of open and clear regulations on recruitment procedures supports equal opportunities for men and women. The intent of the proposals of the Autonomy Inquiry is not that future recruitment will take place in a context devoid of regulations. The intent is that the needed regulations be formulated by the universities. Regulation is thus intended to be local, rather of central. (IR AI 2008 p. 195) (SW)

In the final government proposition, then, the composition of recruitment boards in terms of gender is still subject to central regulation. A new procedure for recruiting full professors through direct recruitment was instituted, designed to facilitate the recruitment of gender minorities.

A third issue is the existence of collegial organisational forms at the universities, that is, the central faculty boards. The previous Higher Education Act stipulated that every university should have a faculty board elected by the faculty members. While it is claimed throughout the inquiry texts that collegial structures are ineffective and incapable of making tough strategic decisions, they are still expected to remain in place:

Many point to the special nature of universities, and that decisions on common academic matters should be made by collegiate bodies elected by the faculty. They are of the opinion that this principle is an essential foundation of academic freedom. [...] Even among autonomy advocates, many think that collegiate decision-making is so important that it must be secured through national legislation. (IR AI 2008 p. 126) (SW)

The final government proposition, therefore, suggested that several decision areas not be left to the discretion of vice-chancellors, but rather to collegiate boards composed of individuals who possess the necessary scientific or artistic competence: 
The government thus proposes that [such decisions] shall require scientific or artistic competence. [Such decisions] should, according to the government, be of the type currently usually within the jurisdiction of faculty boards or special bodies. They may, for example, be different scientific or quality-related matters within teaching and research, such as planning, coordination and evaluation of teaching and research, or advisory and preparatory matters preceding decision-making by the university board and vice-chancellor. (GP AIIT 2010 p. 35-36) (SW)

\section{Tensions and voids: liberated but distrusted leaders, instrumentalisation of leadership and an empty space}

The next step in our analysis is to discuss in what ways there are tensions and voids in the texts, and in what way(s) these tensions are handled. Following O'Reilly and Reed (2010, 2011), we find that there are often tensions between notions of managerialism and leaderism in this material. The higher education sector is framed as one in need of 'strong leadership'-i.e. liberated, empowered leaders that can on their own identify future challenges and decide how to meet them - but they are not trusted to preserve central academic and political values. At the same time, academics and academic leaders are framed as needing much improved surveillance, control and instrumental management—but not motivation, social responsibilisation or organisational conditions tailored to their professional roles and work tasks. The material is lacking in ideas as to how leadership is supposed to work and what it is supposed to deliver - a discursive gap related to the description of certain forms of 'strong' leadership as inevitable and necessary preconditions of desired developments rather than as integral to them. These tensions and voids are summarised in Table 3.

\section{The distrusted liberated leader}

The first tension is based on the leaderist assumption that liberated managers, if given full authority and accountability, can lead their organisations into growth and prosperity. This assumption is not questioned; rather, it is presented as an inevitable necessity, as a fact, as a natural historical development, as a sacred quality (cf. Terry 1998; Grint 2010; Martin and Learmonth 2012). Where generations of politicians and civil servants have failed to govern the academic sector through detailed regulations, empowered managers will succeed if liberated from these regulative shackles. Managers - 'strong leaders', more or less born with leadership as an innate personal quality - are the ones who shall take organisational responsibility, being sure to make the decisions that are best for the organisation as a whole rather than attending to the wishes of individual members of the organisation.

The tension emerging in the material is still one between these vast powers and the continued need for political control in the public sector: empowered leaders are the desired vehicles for steering universities through the hardships of fierce international competition, but at the same time a liberated leader also constitutes a risk that not all government priorities will be attended to. This is a dilemma often discussed in political science but less so in the corporate world: public sector institutions are always more important than their leaders, and must therefore be protected from them. There is always the danger that emancipated leaders 
Table 3 Leaderist themes, tensions and voids

\begin{tabular}{|c|c|c|c|}
\hline $\begin{array}{l}\text { Discursive } \\
\text { themes }\end{array}$ & Theme summaries & Discursive tensions & Discursive voids \\
\hline
\end{tabular}

$\begin{array}{ccc}\begin{array}{c}\text { Traditional and } \\ \text { modern }\end{array} & \begin{array}{c}\text { Higher education faces new } \\ \text { challenges. }\end{array} & \begin{array}{c}\text { No tension in the argument } \\ \text { presented. Strong and }\end{array} \\ \text { leadership } & \begin{array}{c}\text { These new challenges require } \\ \text { modern leadership. }\end{array} & \begin{array}{l}\text { modern academic } \\ \text { leadership an inevitable }\end{array} \\ & \begin{array}{c}\text { Modern leadership is what is } \\ \text { practised outside higher }\end{array} & \begin{array}{l}\text { necessity in the current and } \\ \text { future environment. }\end{array}\end{array}$
education.
Academics as reluctant followers

Academics as reluctant leaders

Circumscribing individual leaders
Strong leadership requires liberated leaders.

Collegiate structures and rights to promotion limit the administrative freedom of leaders.

The collegiate structure does not safeguard academic freedom better than line-based structures.

Academics want only to lead themselves.

Academics resist all other sorts of leadership.

Leadership assignments are expected to be temporary detours from scholarly work and thus contaminated by loyalties to colleagues.

Academic leadership has been spared from assuming employers' responsibilities.

Academic leaders must be able to dismiss staff and prioritise.

Current regulations impinge on academic leaders' possibilities for exercising leadership.

Academic leaders will still be bound to follow central regulations on faculty recruitment.

Academic leaders will still not be trusted to handle gender equality issues.
Argument built on tension: current regulations and archaic traditions have resulted in an uncontrollable situation. Academic freedom constitutes a risk if not operating within control exercised through administrative freedom. Academic leaders must be unleashed.

Argument built on introducing a tension between favoured managerialism and less favoured leaderism: emotional attachment and collegiate loyalties detrimental to effective leadership.

Argument built on tension between management and leadership: leadership as exercising formal managerial duties and general employer responsibilities notwithstanding employee reactions and work satisfaction.

Tension between the liberated professional manager and the circumscribed professionalised academic manager: a liberated leader constitutes a risk that not all government priorities will be attended to. The central strategic issue of
Argument lacks tension due to several voids:

Notions of current performance in the Swedish HiEd sector.

Differences between universities.

Assessments of different forms for leadership and management in relation to academic work processes.

Tensions augmented through absence of follower perspectives:

How to make academic careers attractive?

Difficulties in sustaining academic freedom through administrative control?

Tension augmented through obscuring traditional aspects of academic professionalism:

Academic leaders as primus inter pares?

Academics as led also by peers, professional organisations, external grant providers.

Tension augmented through obscuring core aspects of leaderism:

Leadership as creating enthusiasm, motivation, commitment and loyalty.

Leadership as collectively assuming responsibility for operations.

Conditions for and difficulties in academic leader recruitment and development.

Obscuring the still much strengthened managerial influence of the vice-chancellors on all other staff-related issues, and the increased leeway in defining the tasks of collegiate bodies in relation to the hierarchical chain of 
Table 3 (continued)

\begin{tabular}{llll}
\hline $\begin{array}{l}\text { Discursive } \\
\text { themes }\end{array}$ & Theme summaries & Discursive tensions & Discursive voids \\
\hline & $\begin{array}{l}\text { Academic leaders will still be } \\
\text { bound to sustaining } \\
\text { collegiate bodies. }\end{array}$ & $\begin{array}{l}\text { staff recruitment is not left } \\
\text { in the hands of the liberated } \\
\text { leaders. }\end{array}$ & command. \\
\hline
\end{tabular}

will use their increased powers in a way that violates ethical and cultural standards and serves their personal interests (Lindgren et al. 2011).

In the case of the deregulation studied here, this mistrust is manifested in the partly withdrawn deregulation of collegiate decision structures, key personnel recruitment procedures and gender equality provisions. It is a mistrust that is based on an implicit suspicion that fully empowered vice-chancellors might not resist the temptation to install clear hierarchies, employ whomever they want regardless of merit, and leave the gender equality problem to resolve itself. We have also seen this mistrust expressed in appreciative statements throughout the texts on the need to preserve the distinctive character of academia. This mistrust also exists in the corporate world, but is manifested there in other ways, such as in corporate governance regulations intended to protect shareholders from fraud, overly risky decisions and market manipulations.

Universities, like many other public sector organisations, are subject to various means of justifying actions and policies, and university managers have thus also been expected to simultaneously deliver on expectations of internal effectiveness, bureaucratic control, consumer-friendly knowledge and ideological righteousness (Bolden et al. 2014). This set of expectations has not changed over the course of deregulation, but the Swedish government no longer holds the full legislative power to enforce them. The government wants the empowered leaders as a simple solution to complex problems, but it does not want them to become dictators or blinkered bureaucrats. In the clear-cut rhetorical world of neoliberal principles, forceful leaders should come to the rescue of beleaguered organisations; in the messy world of reality, leaders should not be too forceful, and most organisations not too receptive. Not surprisingly, the Swedish government has again begun to intervene in the higher education sector, e.g. by initiating national gender equality mainstreaming programmes and hindering a university in implementing a decision to close down one of its campuses.

\section{Practising leadership: instrumental management and the distrusted academic}

A basic feature of leaderism is the "belief that many core aspects of social life can and should be co-ordinated by one or more individuals who give direction and/or purpose to social activity conducted by themselves and others' (O'Reilly and Reed 2010: 964). As noted in the previous section, the texts studied draw heavily upon this discursive belief in liberated leaders who can direct and co-ordinate employees in conformity with common strategies and standards. At present, universities are said to respond to rapidly changing external conditions by maintaining internal organisational practises based on disintegration, loosely coupled research groups and self-serving professors. Universities are claimed to perceive themselves as sufficiently led just as they are, ignoring the need to be saved from their own leadership incompetence, oblivious to the future challenges in the global marketplace. They are trapped in a Humboldtian 'ivory tower' notion of universities as being governed in a traditional manner in the pursuit of 
knowledge and truth. It is a notion where professional autonomy always comes before organisational needs, where academic freedom always comes before administrative freedom, where employee retention always comes before strategic change. The reason for this is not only that universities are dominated by slow and ineffective collegiate decision structures, populated by temporary managers on detour from their ordinary positions, but also the established organisational cultures - the problems are not only in the formal structure, but also in the mind-sets of all employees. The typical academic employee is constructed in the texts as an individualist, expecting to be granted a comfortable career based on a personal area of interest as long as he or she continues to adhere to professional norms, and as such does not deserve to be trusted to partake voluntarily in the necessary reform agenda.

It is in this latter thought we find a tension between the leaderist discourse presented as a panacea to the sector and the managerialist instrumentality evident in its prescribed practice. When outlining the alternative ways of developing creative and innovative universities, the texts mainly revert to an instrumental mode, emphasising leadership as both an individualistic and formal responsibility. Given that the higher education sector has been 'spared' (Governmental Public Inquiries 2007), new leaders are expected make full use of their formal authority in recruiting and dismissing staff, formulating policies and governance structures, enforcing physical presence at the workplace, and making decisions on opening up and closing down areas of research depending on external market demand. Consequently, university employees are expected to behave accordingly - by buying into the assumption that leaders and 'followers' have similar interests and values, by acknowledging that academic freedom exists within the bounds of administrative freedom, and by realising that performance is judged according to key performance indicators and external audits rather than peer review, thus submitting to organisational strategies and regulations (cf. Reed 2016).

This tendency in the texts to instrumentalise leadership into traditional management and to suppress the emotional and motivational dimensions of academic leadership and university reflects a desired shift from self-leadership to professional management in universities: whereas the imagined Humboldtian university was governed by collectives of senior faculty and day-to-day work carried out by more or less autonomous academics, the contemporary entrepreneurial university is to be governed by individual professional managers commanding large units with a high degree of work specialisation (cf. Geschwind and Broström 2015). Academics' emotional attachments to universities and subject areas and the relational formation of loyalty and pride amongst them are seen as positive (or indeed acceptable) only insofar as they are of instrumental value.

\section{Discursive void: the (seemingly forgotten) aspects of leaderism}

We also find a discursive 'empty space' emerging as the detailed and well-established Humboldtian notion of the autonomous professional is juxtaposed with new managerialist and leaderist ideals. The 'empty space' emerges where one aspect of one discourse is not reflected in the other - in the absence of alternative conceptions and in the series of unanswered questions accompanying the introduction of managerialism and leaderism. Are managers and academics to become separate employee categories or not? How can long-term planning integrity (holding on to long-term projects and academic principles despite shifting fads and fashions) be organised? What are the new values and the new cultures that should replace the old (dysfunctional) ones? Is 'strong leadership' only about recruiting, retaining and dismissing staff? Is it only about making unpopular decisions? Where are the links between 
leadership and creativity? What about other sources of regulatory power for universities, such as funding bodies and EU standards? How is it possible to separate the organisation of research from the content of research? In what ways are the tasks of the academic sector different from those of government authorities and private corporations? What makes an academic workplace attractive to international top talent? How can gender equality work be taken beyond mere body counting? The absence of any kind of answer to such questions other than that 'strong leadership' and instrumental management per se are necessary is indeed a way of handling discursive tensions, but it leaves the reader with a sense of leadership as "an empty signifier, an open space or 'lack' whose operative function is not to 'exist' in the usual sense but to structure phantasmic attachment” (Jones and Spicer 2005: 235).

Some of these absent issues indeed surfaced in the final inquiry text (Governmental Public Inquiries 2015b). The inquiry could not propose any legislative changes, as universities had already been granted autonomy, but it concluded that most universities had embarked on the desired path towards an increase in hierarchical managerial structures and clear regulation of authority and accountability. The internal organisational structures differed, as did the views on leadership, but within the bounds of the 2010 bill. The inquiry made a distinction between a small group of 'older' universities that still gave collegiate bodies significant formal influence over internal matters, and a resulting large group of new universities where all formal decisions had been assigned to officials in the formal chain of command. It was recommended that the former should learn from the latter.

\section{Conclusion: leadership as panacea and void}

This paper is rooted in a need to understand government deregulation of the Swedish university sector as a discursive process, focusing on how management and leadership are articulated and understood. The aim was to inquire into how tensions within and between managerialist and leaderist discourse are handled in the promotion of New Public Management reforms and the consequences thereof in terms of how leadership in the higher education sector is constructed. We thus intended to add to earlier studies on higher education reform and leadership (cf. Reed 2002; Deem 2004; Bleiklie and Lange 2010; Clarke et al. 2012; Bolden et al. 2014) by providing a conceptualisation of how different discursive influences are simultaneously invoked in the ongoing production of organisational truths.

In our reading of the government texts, we have discerned several discursive themes that link back to two underlying discourses on leadership in higher education (cf. Deem 2004). The emerging 'leaderist' discourse (O'Reilly and Reed 2010) is, as described above, forcefully advocated throughout the material, but without much detailed content beyond the emphasis on empowered professional vice-chancellors as the inevitable solution to the complex future problems that the sector is facing. Its counterpoint is the rhetorical framing of an ineffective and secluded cultural tradition in the higher education sector that permits universities and academics to be self-led or un-led within existing regulatory boundaries, relying on professionalism, collegiate decision-making, weak managers and individual autonomy. While the contents of this undesired tradition are presented in a rather detailed manner and as more or less homogenous throughout the sector, its consequences and disadvantages are described only in vague terms. Leaderism is necessary for the survival of the sector, but not much is said about what extant problems it is supposed to solve or how it is supposed to operate. The literature on leaders and leadership is full of ideas that could have formed the foundation of a more careful analysis of the functioning of both empowered managers and collegiate 
structures, but they are nowhere to be found in the texts studied, except from the non-legislative Governmental Public Inquiries (2015b). The day-to-day management of universities is instead expected to resort to traditional New Public Management in terms of increased surveillance, control and instrumentalism (Ahlbäck Öberg et al. 2016).

What then are the wider implications of our study? In practical terms, the discursive patterns described here could hopefully be employed in informed discussions on leadership and management in future Swedish higher education. When forming expectations on academic leadership, it should be of essence to analyse all alternative forms in detail rather than-as indicated here - promoting a certain ideology by neglecting its inner tensions and suppressing important aspects such as motivation and commitment. This is important not least because general discourses are invoked at the local level and contribute to identity construction amongst academic leaders (and their 'followers'). Where research is concerned, we hope to have added to extant studies of leaderism in the public sector (cf. O'Reilly and Reed 2010, 2011; Martin and Learmonth 2012; Bresnen et al. 2015) by showing how simplistic assumptions on the primacy of individual leadership find their way into well-informed and powerful groupings of actors (all inquiry teams were headed by full professors, former vice-chancellors and ministers) and rapidly come to be taken as an established truth-while at the same time noting the political reluctance to give those in leadership positions full freedom in their pursuits. Further scholarly work on the policy process and its effects on the practise of leadership and management in higher education would thus be needed.

An interesting question arising from the texts analysed is, of course, 'How is it that farreaching deregulation and far-reaching critiques of current practices and cultures in Sweden's academic sector are acceptable in public debate?' The answer is partly linked to the new liberal/conservative government that was in power during the period 2006-2014 and that implemented the deregulation, but it is a far from sufficient explanation. Rather, the answer to the question is to be found in long-term developments related to the long-term discursive shift discussed in this paper: the academic sector increasingly fulfilling a functional role in purposebuilt societal innovation systems; the increased reliance on higher education as a part of labour market policies; the creeping specialisation and collectivisation of teachers and researchers in the wake of increased industrialisation of higher education; and the increased focus on top civil servants in the public sector efficiency debate (cf. Marginson and Considine 2000; Berglund 2008; Hoofd 2010; Mathisen Nyhagen and Baschung 2013; Geschwind and Broström 2015; Reed 2016). This has implied consequences for individual higher education employees in terms of new available subjectivities (Peters 2001; Trowler 2001), as managerialist and leaderist discourses in the public sector are part of an emerging enterprise culture in which notions of employability, flexibility, project orientation and individual responsibilisation become central to our way of justifying and regulating our existence and our actions (Peters 2001).

A general metaphorical impression of the texts is that the ongoing discursive shift in the view of the relationship between government and universities implies a 'black-boxing' of academic leadership. The traditional system, built upon detailed central regulation, was transparent in the sense that rules were clear and were the same for everybody (although not always honoured to the same standards). Deregulation has left us with a discursive empty space, a black box where we know the input and the intended outcomes, that is, flexible, high-quality, path-breaking and everchanging universities. We know almost nothing, however, about the intended leadership practises - who will carry them out, what these leaders will say and do, and what can and should be said and done - except for one thing: there will be leadership. 
Acknowledgements The authors would like to thank the editor, Rosemary Deem, and the three anonymous reviewers for their most constructive and helpful comments in revising this article for publication. We are also indebted to the convenors and participants of the 2010 International Studying Leadership Conference, Lund, Sweden, in which an earlier version of this paper was presented, and to the working paper seminar in Industrial Economics and Management at KTH Royal Institute of Technology. We especially appreciate the comments and suggestions made by Lucia Crevani and André Spicer. Funding for this research was provided by the Swedish Governmental Agency for Innovation Systems (VINNOVA) and the Swedish Foundation for Humanities and Social Sciences (RJ), which is hereby gratefully acknowledged.

Open Access This article is distributed under the terms of the Creative Commons Attribution 4.0 International License (http://creativecommons.org/licenses/by/4.0/), which permits unrestricted use, distribution, and reproduction in any medium, provided you give appropriate credit to the original author(s) and the source, provide a link to the Creative Commons license, and indicate if changes were made.

\section{References}

Ahlbäck Öberg, S., Bull, T., Hasselberg, Y., \& Stenlås, N. (2016). Professions under siege. Statsvetenskaplig tidskrift, 118(1), 93-126.

Alvesson, M., \& Spicer, A. (2012). Critical leadership studies: The case for critical performativity. Human Relations, 65(3), 367-390.

Ball, S. (2003). The teacher's soul and the terrors of performativity. Journal of Education Policy, 18(2), 215-228.

Berglund, E. (2008). I wanted to become an academic, not 'a creative': Notes on universities and the new capitalism. Ephemera: theory \& politics in organization, 8(3), 322-330.

Berglund, K., Lindgren, M., \& Packendorff, J. (2017) Responsibilising the next generation: Fostering the enterprising self through de-mobilising gender. Organization (forthcoming).

Bleiklie, I., \& Lange, S. (2010). Competition and leadership as drivers in German and Norwegian university reforms. Higher Education Policy, 23(2), 173-193.

Bolden, R., Gosling, J., \& O'Brien, A. (2014). Citizens of the academic community? A societal perspective on leadership in UK higher education. Studies in Higher Education, 39(5), 754-770.

Bresnen, M., Hyde, P., Hodgson, D., Bailey, S., \& Hassard, J. (2015). Leadership talk: From managerialism to leaderism in health care after the crash. Leadership, 11(4), 451-470.

Clarke, J., \& Newman, J. (1997). The managerial state: Power, politics and ideology in the remaking of social welfare. London: Sage.

Clarke, C., Knights, D., \& Jarvis, C. (2012). A labour of love? Academics in business schools. Scandinavian Journal of Management, 28(1), 5-15.

Collinson, D. (2014). Dichotomies, dialectics and dilemmas: New directions for critical leadership studies. Leadership, 10(1), 36-55.

Crevani, L., Lindgren, M., \& Packendorff, J. (2007). Shared leadership: A post-heroic perspective on leadership as a collective construction. International Journal of Leadership Studies, 3(1), 40-67.

Crevani, L., Lindgren, M., \& Packendorff, J. (2010). Leadership, not leaders: On the study of leadership as practices and interactions. Scandinavian Journal of Management, 26(1), 77-86.

Crevani, L., Ekman, M., Lindgren, M., \& Packendorff, J. (2015). Leadership cultures and discursive hybridisation: On the cultural production of leadership in higher education reforms. International Journal of Public Leadership, 11(3/4), 147-165.

Currie, G., \& Lockett, A. (2007). A critique of transformational leadership: Moral, professional and contingent dimensions of leadership within public services organizations. Human Relations, 60(2), 341-370.

Deem, R. (2004). The knowledge worker, the manager-academic and the contemporary UK university: New and old forms of public management? Financial Accountability \& Management, 20(2), 107-128.

Denis, J.-L., Langley, A., \& Sergi, V. (2012). Leadership in the plural. Academy of Management Annals, 6(1), 211-283.

Fitzgerald, L., Ferlie, E., McGivern, G., \& Buchanan, D. (2013). Distributed leadership patterns and service improvement: Evidence and argument from English healthcare. The Leadership Quarterly, 24(1), 227-239.

Ford, J. (2006). Discourses of leadership: Gender, identity and contradiction in a UK public sector organization. Leadership, 2(1), 77-99.

Geschwind, L., \& Broström, A. (2015). Managing the teaching-research nexus: Ideals and practice in researchoriented universities. Higher Education Research \& Development, 34(1), 60-73.

Gleeson, D., \& Knights, D. (2006). Challenging dualism: Public professionalism in troubled times. Sociology, 40(2), 277-295. 
Governmental Public Inquiries (2007) Karriär för kvalitet [Careers for quality]. SOU 2007:98. Stockholm: Fritzes. [http:/www.regeringen.se/contentassets/263d71e9a072477894b8b371173d8405/karriar-for-kvalitethela-dokumentet-sou-200798].

Governmental Public Inquiries (2008) Självständiga lärosäten [Autonomous universities]. SOU 2008:104. Stockholm: Fritzes. [http://www.regeringen.se/contentassets/e23c5b1112974ed3b52d1eb439ee3152 /sjalvstandiga-larosaten-sou-2008104].

Governmental Public Inquiries (2015a) Delrapport från ledningsutredningen [Partial report from the Management Inquiry]. U2014:11. Stockholm: Ministry of Education. [http://www.regeringen. se/contentassets/bdd1169ba0d04e8d91a043074681a953/delrapport-fran-ledningsutredningen.pdf].

Governmental Public Inquiries (2015b) Utvecklad ledning av universitet och högskolor [Developed management of higher education institutions]. SOU 2015:92. Stockholm: Wolters Kluwers. [http://www.regeringen. se/contentassets/8f7d8be9a47a4b2ea6baa1e48173bf84/utvecklad-ledning-av-universitet-och-hogskolor-sou2015 92.pdf].

Grint, K. (2010). The sacred in leadership: Separation, sacrifice and silence. Organization Studies, 31(01), 89107.

Holgersson, C. (2013). Recruiting managing directors: Doing homosociality. Gender, Work and Organization, 20(4), 454-466.

Hood, C. (1995). The 'new public management' in the 1980's: Variations on a theme. Accounting, Organizations and Society, 20(2/3), 93-109.

Hoofd, I. M. (2010). The accelerated university: Activist-academic alliances and the simulation of thought. Ephemera: theory \& politics in organization, 10(1), 7-24.

Jones, C., \& Spicer, A. (2005). The sublime object of entrepreneurship. Organization, 12(2), 223-246.

Lindgren, M., Packendorff, J., \& Tham, H. (2011). Relational dysfunctionality: Leadership interactions in a Sarbanes-Oxley act implementation project. European Journal of International Management, 5(1), 13-29.

Marginson, S., \& Considine, M. (2000). The Enterprise University: Power, governance and reinvention in Australia. Oakleigh: Cambridge University Press.

Martin, G. P., \& Learmonth, M. (2012). A critical account of the rise and spread of 'leadership': The case of UK healthcare. Social Science \& Medicine, 74, 281-288.

Mathisen Nyhagen, G., \& Baschung, L. (2013). New organisational structures and the transformation of academic work. Higher Education, 66, 409-423.

Meindl, J. R., Ehrlich, S. B., \& Dukerich, J. M. (1985). The romance of leadership. Administrative Science Quarterly, 30, 78-102.

Morrish, L., \& Sauntson, H. (2010). Gender and sexuality: The discursive limits of 'equality' in higher education. Learning and Teaching, 3(2), 1-18.

O'Reilly, D., \& Reed, M. (2010). 'Leaderism': An evolution of managerialism in UK public service reform. Public Administration, 88(4), 960-978.

O'Reilly, D., \& Reed, M. (2011). The grit in the oyster: Managerialism and leaderism as discourses of UK public services modernization. Organization Studies, 32(8), 1079-1101.

Peters, M. (2001). Education, enterprise culture and the entrepreneurial self: A Foucauldian perspective. Journal of Educational Enquiry, 2(2), 58-71.

Pollitt, C. (1990). Managerialism and the public service: The Anglo-American experience. Cambridge: Basil Blackwell.

Reed, M. (2002). New managerialism, professional power and organizational governance in UK universities. In A. Amaral, G. Jones, \& B. Karseth (Eds.), Governing higher education: National Perspectives on institutional governance. Dordrecht: Kluwer.

Reed, M. I. (2016). Leadership and 'leaderism': The discourse of professional leadership and the practice of management control in public services. In M. Dent, I. L. Bourgeault, J.-L. Denis, \& E. Kuhlmann (Eds.), The Routledge companion to the professions and professionalism (pp. 200-214). Oxon: Routledge.

Stenson, K., \& Watt, P. (1999). Governmentality and 'the death of the social'? A discourse analysis of local government texts in south-east England. Urban Studies, 36(1), 189-201.

Swedish Government (2006) Befattningsstruktur vid universitet och högskolor [Employment structures at universities and university colleges]. Dir. 2006:48. Stockholm: Swedish Government. [http://www. riksdagen.se/sv/dokument-lagar/dokument/kommittedirektiv/befattningsstruktur-vid-universitet-ochhogskolor_GUB148.

Swedish Government (2007) Ökad frihet för universitet och högskolor [Increased freedom for universities and university colleges]. Dir. 2007:158. Stockholm: Swedish Government. [http://www.regeringen. se/contentassets/352aea3f6c9f4cde9f0715094bc09e2c/okad-frihet-for-universitet-och-hogskolor-dir.2007158].

Swedish Government (2010) En akademi i tiden - ökad frihet för universitet och högskolor [An academy in its time - increased freedom for universities and university colleges]. Prop. 2009/10:149. Stockholm: Swedish 
Government. [http://www.regeringen.se/contentassets/07a972fdbfdd43789da5a5b03dbb6f4a/en-akademi-itiden-okad-frihet-for-universitet-och-hogskolor-prop.-200910149].

Swedish Government (2014) Ledningsfunktioner i högskolan [Management functions in higher education]. Dir. 2014:70. Stockholm: Swedish Government. [http://www.regeringen.se/contentassets/99a0f60d964a43319a5 a6320172d6a73/ledningsfunktioner-i-hogskolan-dir--201470].

Swedish Government (2015) Tilläggsdirektiv till Ledningsutredningen [Additional directives to the Management Inquiry]. Dir. 2015:44. Stockholm: Swedish Government. [http://www.regeringen.se/contentassets/0264899 d18704d21947c9387c9e2a68b/tillaggsdirektiv-till-ledningsutredningen-u-201411-dir.-201544].

Teelken, C. (2012). Compliance or pragmatism: How do academics deal with managerialism in higher education? A comparative study in three countries. Studies in Higher Education, 37(3), 271-290.

Terry, L. D. (1998). Administrative leadership, neo-managerialism, and the public management movement. Public Administration Review, 58(3), 194-200.

Trowler, P. (2001). Captured by the discourse? The socially constitutive power of new higher education discourse in the UK. Organization, 8(2), 183-201.

Van den Brink, M., \& Stobbe, L. (2014). The support paradox: Overcoming dilemmas in gender equality programs. Scandinavian Journal of Management, 30(2), 163-174.

Wahl, A. (2014). Male managers challenging and reinforcing the male norm in management. NORA-Nordic Journal of Feminist and Gender Research, 22(2), 131-146.

Zoller, H. M., \& Fairhurst, G. T. (2007). Resistance leadership: The overlooked potential in critical organization and leadership studies. Human Relations, 60(9), 1331-1360. 